\title{
Comparative Analysis of Histological Changes in Ussurian Bullhead, Leiocassis ussuriensis, and Korean Bullhead, Pseudobagrus fulvidraco, in the Early Period of Growth
}

\author{
${ }^{\dagger}$ In Bon Goo, Hyun Woo Gil and In-Seok Park \\ Division of Marine Environment and Bioscience, Korea Maritime and Ocean University, \\ Busan 606-791, Republic of Korea
}

\begin{abstract}
The histological changes in the Ussurian bullhead, Leiocassis ussuriensis, and the Korean bullhead, Pseudobagrus fulvidraco, were observed during the early period of growth. The retinas size of both species increased in the 9 days post-hatching (DPH) $(p<0.05)$. In the just-hatched Ussurian bullhead, the retina already consisted of six layers: the epithelial layer, ganglion cell layer, inner nuclear layer, inner plexiform layer, outer limiting membrane layer, and rod and cone layer. The Korean bullhead had the same components. At $50 \mathrm{DPH}$, the thickness of the retina was $538.0 \pm 7.19 \mu \mathrm{m}$ in the Ussurian bullhead and 558.9 $\pm 9.44 \mu \mathrm{m}$ in the Korean bullhead. The relative thickness of each layer of the retina did not differ significantly in the two species. Although the growth of the Korean bullhead's retina was faster, the relative thickness of each layer in the retina did not change during early development. After hatching, some parts of the tissue gradually became denser. Immediately after hatching, the kidney and midgut epithelium of the Ussurian bullhead and Korean bullhead were already formed and grew gradually thereafter. From $0 \mathrm{DPH}$ to $30 \mathrm{DPH}$, the nuclear height in the midgut epithelium did not differ significantly between the two species, but at $50 \mathrm{DPH}$, it was $11.4 \pm 2.45 \mu \mathrm{m}$ in the Korean bullhead and $9.9 \pm$ $2.13 \mu \mathrm{m}$ in the Ussurian bullhead. During the experimental period, the major axes, minor axes, surface areas, and volumes of the proximal tubule cells in the kidney did not differ significantly between the two species. Thus, the early histological development of the Ussurian bullhead is similar to that of the Korean bullhead.
\end{abstract}

Key words : Histology, Korean bullhead, Pseudobagrus fulridraco, Ussurian bullhead, Leiocassis ussuriensis

\section{INTRODUCTION}

The Ussurian bullhead, Leiocassis ussuriensis, is a fish species of the family Bagridae. It occurs in the Daedong River, Amnok River, Imjin River, Han River, and Geum River of Korea, and has also recently been found in the Nakdong River of Korea (Kim \& Park, 2002). It is a nocturnal fish that lives in rivers with slow currents, on river bottoms composed of mud or sand. With its chewy flesh and excellent umami taste, it is an essential ingredient of the local spicy freshwater fish stew, together with the Korean bullhead, Pseudobagrus fulvidraco (Lim et al., 2012).

The Korean bullhead, which also belongs to the family Bagridae (Park \& Lee, 1996), is found throughout Asia, including Korea, and commonly inhabits the West Sea and South Sea flows into the midstream and downstream of the rivers in Korea (Park \& Lee, 1996; Kim \& Park, 2002). The Korean bullhead has no scales on its body and its head is flat. It is a predominantly carnivorous fish, feeding at night, so its habit is nocturnal (Lee, 1993).

\footnotetext{
Manuscript received 24 November 2013, Received in revised form 10 December 2013, Accepted 15 December 2013

${ }^{\dagger}$ Corresponding Author : In Bon Goo, Division of Marine Environment Bioscience, College of Ocean Science and Technology, Korea Maritime and Ocean University, Busan 606-791, Republic of Korea. Tel. : +82-51-410-4321, Fax : +82-51-405-4322, E-mail : bourne@kmou.ac.kr

This is an Open Access article distributed under the terms of the Creative Commons Attribution Non-Commercial License (http://creativecommons. org/licenses/by-nc/3.0) which permits unrestricted non-commercial use, distribution, and reproduction in any medium, provided the original work is properly cited.
} 
The Korean bullhead is considered to have a spectacular taste and is widely used as the main ingredient in spicy freshwater fish stews, as are catfish and carp, and the demand for this fish is therefore increasing (Lee, 1993).

The visual function of fish larvae is important for their feeding, positioning, collective behavior, and escape from predators (Rodriguez \& Gisbert, 2001; Park et al., 2006a, 2006b). The retinal structure of the Teleostei does not differ from that of other vertebrates, but the number of teleost species and their various habitats, activities, and life cycles make it difficult to define a general retinal structure for the Teleostei (Wagner, 1990). The behavioral and environmental factors affecting different fish are important to their visual ecology and to any study of their visual structures and function (Walls, 1942; Lythgoe, 1979).

There has been much research into yolk absorption and early growth in the rainbow trout, Oncorhynchus mykiss (Park et al., 1996) and chum salmon, O. keta (Zhang et al., 1995), and into the eye development of the dotted gizzard shad, Konosirus punctatus (Park et al., 2006a) and the dark-banded rockfish, Sebastes inermis (Park et al., 2012), and morphometric and hitological changes in the cyprinid loach, Misgurnus anguillicaudatus (Han et al., 2013). Generally, the development of an internal organ, such as the kidney or midgut epithelium, proceeds throughout the larval stage (Blaxter, 1988). However, there have been insufficient studies of the Ussurian bullhead and Korean bullhead. Also, the Ussurian bullhead and Korean bullhead have similar habitats and spawning seasons. Comparative histological analysis two species is semantic. Therefore, the aim of this study was to observe the histological development of these two species, which should provide important indices for basic research into the internal changes that occur in Bagridae larvae.

\section{MATERIALS AND METHODS}

\section{Experimental fish}

In this study, we examined juvenile specimens of the
Ussurian bullhead, Leiocassis ussuriensis, and the Korean bullhead, Pseudobagrus fulvidraco. On June 28, 2012, we fertilized eggs of the two species, which were reared and bred at the Fisheries Genetics and Breeding Sciences Laboratory, Korea Maritime and Ocean University, Busan, Republic of Korea. The larvae were fed three times a day (08:00, 12:00, and 17:00 h) exclusively with Artemia metanauplii (Salt Creek Inc., Salt Lake City, UT, USA). The larvae were reared in 10 tanks $(100 \mathrm{~L})$ that included a circulation pump, an aeration system, and a temperature control system. Dissolved oxygen levels were maintained with an air pump, and the water temperature was maintained at $26 \pm 0.5^{\circ} \mathrm{C}$.

\section{Histological observations}

We extracted the eye, kidney, and midgut epithelium needed for histological observation from each species at $50 \mathrm{DPH}$. Each sample was fixed in Bouin's solution for $24 \mathrm{~h}$ and then washed in flowing water. The samples were then processed in decalcification solution for $24 \mathrm{~h}$, washed again, and dehydrated through a graded series of alcohol (70\%, 80\%, 90\%, and 100\% alcohol for $1 \mathrm{~h}$ each). The samples were then cleared with xylene and impregnated with soft paraffin and hard paraffin. After impregnation, the samples were embedded, trimmed, and cut. It stained with hematoxylin-eosin. The samples were then mounted with Canadian balsam, examined with an optical microscope, and photographed with an optical microscope camera (AxioCam MR, Carl Zeiss, Germany).

Using an eyepiece micrometer under an optical microscope (Carl Zeiss, Germany), samples of each species, ranging from just hatched to $50 \mathrm{DPH}$, were randomly selected and the retinal thickness measured. We calculated the proportional thicknesses of the epithelial layer (EL), rod and cone layer (RCL), outer limiting membrane layer (OLM), inner nuclear layer (INL), inner plexiform layer (IPL) and ganglion cell layer (GCL) of the retinas, using the method of Park et al. (2006b), in just-hatched, 10 $\mathrm{DPH}, 30 \mathrm{DPH}$, and $50 \mathrm{DPH}$ specimens of both species. To determine the development of the kidney and midgut 
epithelium, a biological microscope was used to measure the areas and volumes of the cells and nuclei using the following formulae: surface area $=1 / 4 \times a b \pi$, and volume $=$ $4 / 3 \times \pi(a / 2) \times(b / 2)^{2}$, where $a=$ the major axis of the cell or nucleus; $b=$ the minor axis of the cell or nucleus (Park \& Kim, 2000). We also photographed the eye structure and the developmental stages of the kidney and midgut epithelium in each just-hatched and 50 DPH specimen using the Axioskop 4.1 image analysis software (Carl Zeiss, Germany).

\section{Statistical analysis}

The experiment was performed in triplicate and the results are reported as means $\pm \mathrm{SD}(n=30)$, unless otherwise stated. The data were analyzed with one-way ANOVA using the SPSS statistical package (SPSS 9.0, SPSS Inc., Chicago, IL, USA). Means were compared with Duncan's multiple range test, and were considered significantly different at $p<0.05$.

\section{RESULTS}

Table 1 lists the component layers of the retina in the Ussurian bullhead, Leiocassis ussuriensis, from just-hatched to $50 \mathrm{DPH}$. The thickness of the retina increased continuously from $92.4 \mu \mathrm{m}$ to $538.0 \mu \mathrm{m}$ in $50 \mathrm{DPH}(p<0.05)$.
The retina consisted of the EL, RCL,OLM, INL, IPL, GCL,and lens (L). The thickness of the EL, RCL, OLM, and IPL increased, but the INL and GCL decreased in thickness in $50 \mathrm{DPH}(p<0.05)$. The thickness of the RCL increased most rapidly and the thickness of the GCL decreased most dramatically of all the component layers in this period $(p<0.05)$. In case of Korean bullhead, Pseudobagrus fulvidraco, the component layers of the retina from justhatched to $50 \mathrm{DPH}$ shown at Table 2. The retinal thickness increased continuously in common with Ussurian bullhead from $99.1 \mu \mathrm{m}$ to $558.9 \mu \mathrm{m}$ during $50 \mathrm{DPH}(p<0.05)$. Also, the Korean bullhead retina consisted such as EL, RCL, OLM, INL, IPL GCL, and L. Likewise, the thickness of the EL, RCL, OLM and IPL increased, the thickness of the INL and GCL decreased during $50 \mathrm{DPH}(p<0.05)$. The thickness of the RCL increased most rapidly and that of the GCL decreased most dramatically of all the component layers in this period $(p<0.05)$. Thus, both species showed similar trends in retinal development, with the INL and GCL decreasing and the RCL increasing rapidly. The increase in retinal thickness was faster in the Korean bullhead than in the Ussurian bullhead, but the relative proportions of the retinal layers did not differ significantly between the two species. Although the retinal growth of the Korean bullhead was faster, the relative proportions of the retinal layers did not change during early

Table 1. Thickness of each component layer of the retina in the Ussurian bullhead, Leiocassis ussuriensis, from hatching to 50 days post-hatching*

\begin{tabular}{|c|c|c|c|c|}
\hline & \multicolumn{4}{|c|}{ Days post-hatching } \\
\hline & 0 & 10 & 30 & 50 \\
\hline Thickness of 1retina ( $\mu \mathrm{m})$ & $92.4 \pm 5.24$ & $13 / . \angle \pm 3.8 ర$ & $41 \angle .4 \pm / .14 \mathrm{c}$ & $538.0 \pm 7.19^{\mathrm{d}}$ \\
\hline \multicolumn{5}{|l|}{ Thickness of each layer of retina (\%) } \\
\hline Epithelial layer & $4.0 \pm 0.13^{\mathrm{a}}$ & $4.2 \pm 0.19^{\mathrm{ab}}$ & $4.6 \pm 0.31^{\mathrm{b}}$ & $5.5 \pm 0.28^{\mathrm{c}}$ \\
\hline Rod and cone layer & $8.9 \pm 0.28^{\mathrm{a}}$ & $9.9 \pm 0.43^{b}$ & $13.4 \pm 0.87^{\mathrm{c}}$ & $21.5 \pm 1.10^{d}$ \\
\hline Outer limiting membrane layer & $4.1 \pm 0.13^{\mathrm{a}}$ & $4.3 \pm 0.18^{\mathrm{a}}$ & $5.2 \pm 0.24$ & $6.8 \pm 0.35^{\mathrm{b}}$ \\
\hline Inner nuclear layer & $10.5 \pm 0.53^{\mathrm{a}}$ & $8.6 \pm 0.48^{\mathrm{b}}$ & $7.8 \pm 0.40^{\mathrm{bc}}$ & $7.4 \pm 0.38^{\mathrm{C}}$ \\
\hline Inner plexiform layer & $21.5 \pm 0.69^{\mathrm{a}}$ & $22.0 \pm 0.81^{\mathrm{a}}$ & $23.1 \pm 0.98^{\mathrm{b}}$ & $25.2 \pm 1.30^{\mathrm{c}}$ \\
\hline Ganglion cell layer & $17.0 \pm 0.53^{\mathrm{a}}$ & $10.1 \pm 0.58^{\mathrm{b}}$ & $7.9 \pm 0.41^{\mathrm{c}}$ & $6.6 \pm 0.34^{\mathrm{d}}$ \\
\hline
\end{tabular}

* The values are means \pm SD $(n=30)$ of triplicate groups. Differences among the experimental groups were significant at this level. Values in the same column not sharing a superscript letter are significantly different $(p<0.05)$. 
IB Goo, HW Gil, I-S Park

Table 2. Thickness of each component layer of the retina of the Korean bullhead, Pseudobagrus fulvidraco, from hatching to 50 days post-hatching*

\begin{tabular}{|c|c|c|c|c|}
\hline & \multicolumn{4}{|c|}{ Days post-hatching } \\
\hline & 0 & 10 & 30 & 50 \\
\hline Thickness of retina $(\mu \mathrm{m})$ & $99.1 \pm 4.18$ & $141 . U \pm 4.01$ & $4 \angle L .8 \pm 8.04 \mathrm{c}$ & $558.9 \pm 9.44^{d}$ \\
\hline \multicolumn{5}{|c|}{ Thickness of each layer of retina (\%) } \\
\hline Epithelial layer & $4.1 \pm 0.13^{\mathrm{a}}$ & $4.5 \pm 0.21^{\mathrm{ab}}$ & $4.8 \pm 0.41^{\mathrm{b}}$ & $5.7 \pm 0.58^{\mathrm{C}}$ \\
\hline Rod and cone layer & $8.4 \pm 0.16^{\mathrm{a}}$ & $9.7 \pm 0.56^{b}$ & $13.5 \pm 0.77^{\mathrm{c}}$ & $21.2 \pm 1.43^{\mathrm{d}}$ \\
\hline Outer limiting membrane layer & $4.2 \pm 0.23^{\mathrm{a}}$ & $4.4 \pm 0.24^{\mathrm{a}}$ & $5.5 \pm 0.54^{\mathrm{ab}}$ & $6.9 \pm 0.65^{b}$ \\
\hline Inner nuclear layer & $10.7 \pm 0.43^{\mathrm{a}}$ & $8.9 \pm 0.67^{\mathrm{b}}$ & $7.4 \pm 0.51^{\mathrm{bc}}$ & $7.4 \pm 0.88^{\mathrm{C}}$ \\
\hline Inner plexiform layer & $21.4 \pm 0.91^{\mathrm{a}}$ & $22.2 \pm 0.79^{\mathrm{ab}}$ & $23.4 \pm 0.99^{\mathrm{b}}$ & $25.4 \pm 1.41^{\mathrm{c}}$ \\
\hline Ganglion cell layer & $17.2 \pm 0.63^{\mathrm{a}}$ & $10.3 \pm 0.78^{\mathrm{b}}$ & $7.6 \pm 0.88^{\mathrm{c}}$ & $6.7 \pm 0.56^{\mathrm{d}}$ \\
\hline
\end{tabular}

* The values are means \pm SD $(n=30)$ of triplicate groups. Differences among experimental groups are significant at this level. Values in the same column not sharing a superscript letter are significantly different $(p<0.05)$.

development.

Table 3 lists the nuclear heights of the midgut epithelium cells and the cellular dimensions of kidney in the proximal renal tubules of the Ussurian bullhead at just-hatched, 10 $\mathrm{DPH}, 30 \mathrm{DPH}$, and $50 \mathrm{DPH}$. The nuclear height in the midgut epithelium increased continuously from just-hatched to $50 \mathrm{DPH}(p<0.05)$. The major axes and minor axes of the proximal tubule cells in the kidney increased with time, and the minor axes were shorter than the major axes throughout this period $(p<0.05)$. The surface areas and volumes of the renal proximal tubule cells increased dramatically with time $(p<0.05)$. Table 4 lists the nuclear heights in the midgut epithelium and the dimensions of the cells in the renal proximal tubule of the Korean bullhead at just-hatched, $10 \mathrm{DPH}, 30 \mathrm{DPH}$, and $50 \mathrm{DPH}$. The nuclear height in the midgut epithelium increased continuously from just-hatched to $50 \mathrm{DPH}(p<0.05)$. The major axes and minor axes of the proximal tubule cells in the kidney increased with time, and the minor axes were always shorter than the major axes $(p<0.05)$. The surface areas and volumes of the renal proximal tubule cells increased dramatically with time $(p<0.05)$. Thus, the two species showed similar trends in these parameters, with increases in nuclear height and cell size as development progressed.

Table 3. Cell size in the proximal tubule of the kidney and nuclear height in the midgut epithelium of the Ussurian bullhead, Leiocassis ussuriensis, from hatching to 50 days post-hatching*

\begin{tabular}{|c|c|c|c|c|}
\hline & \multicolumn{4}{|c|}{ Days post-hatching } \\
\hline & 0 & 10 & 30 & 50 \\
\hline Nuclear height of midgut epithelium $(\mu \mathrm{m})$ & $4.1 \pm 0.34^{\mathrm{a}}$ & $6.9 \pm 1.81^{\mathrm{a}}$ & $8.1 \pm 2.05^{b}$ & $9.9 \pm 2.13^{\mathrm{C}}$ \\
\hline \multicolumn{5}{|l|}{ Proximal tubule cell of kidney } \\
\hline Major axis $(\mu \mathrm{m})$ & $3.1 \pm 0.22^{\mathrm{a}}$ & $4.0 \pm 0.39^{\mathrm{b}}$ & $6.8 \pm 0.64^{\mathrm{c}}$ & $9.8 \pm 1.30^{\mathrm{d}}$ \\
\hline Minor axis $(\mu \mathrm{m})$ & $2.2 \pm 0.36^{\mathrm{a}}$ & $3.1 \pm 0.30^{\mathrm{a}}$ & $4.2 \pm 0.39^{\mathrm{ab}}$ & $7.3 \pm 0.55^{\mathrm{b}}$ \\
\hline Surface area $\left(\mu m^{2}\right)$ & $5.3 \pm 0.41^{\mathrm{a}}$ & $9.7 \pm 0.69^{\mathrm{b}}$ & $22.4 \pm 3.29^{c}$ & $56.1 \pm 4.59^{\mathrm{d}}$ \\
\hline Volume $\left(\mu \mathrm{m}^{3}\right)$ & $7.8 \pm 1.44^{\mathrm{a}}$ & $20.1 \pm 2.55^{\mathrm{b}}$ & $62.7 \pm 9.11^{\mathrm{c}}$ & $273.3 \pm 20.14^{\mathrm{d}}$ \\
\hline
\end{tabular}

* The values are means \pm SD $(n=30)$ of triplicate groups. Differences among experimental groups are significant at this level. Values in the same column not sharing a superscript letter are significantly different $(p<0.05)$. Surface area $=1 / 4 \times a b \pi$ and volume $=4 / 3 \times \pi(a / 2)$ $\times(b / 2)^{2}$, where $a=$ the major axis of the cell or nucleus, $b=$ the minor axis of the cell or nucleus (Park \& Kim, 2000). 
Histological Changes in Leiocassis ussuriensis and Pseudobagrus fulvidraco

Table 4. Cell size in the proximal tubule of the kidney and nuclear height in the midgut epithelium of the Korean bullhead, Pseudobagrus fulvidraco, from hatching to 50 days post-hatching*

\begin{tabular}{|c|c|c|c|c|}
\hline & \multicolumn{4}{|c|}{ Days post-hatching } \\
\hline & 0 & 10 & 30 & 50 \\
\hline Nuclear height of midgut epithelium $(\mu \mathrm{m})$ & $4.5 \pm 0.54^{\mathrm{a}}$ & $6.9 \pm 1.83^{\mathrm{a}}$ & $9.0 \pm 2.15^{\mathrm{b}}$ & $11.4 \pm 2.45^{\mathrm{C}}$ \\
\hline \multicolumn{5}{|l|}{ Proximal tubule cell of kidney } \\
\hline Major axis $(\mu \mathrm{m})$ & $3.2 \pm 0.29^{\mathrm{a}}$ & $3.9 \pm 0.41^{b}$ & $6.9 \pm 0.68^{\mathrm{c}}$ & $9.7 \pm 1.65^{\mathrm{d}}$ \\
\hline Minor axis $(\mu \mathrm{m})$ & $2.3 \pm 0.39^{\mathrm{a}}$ & $3.2 \pm 0.32^{\mathrm{a}}$ & $4.3 \pm 0.41^{\mathrm{ab}}$ & $7.4 \pm 0.55^{\mathrm{b}}$ \\
\hline Surface area $\left(\mu \mathrm{m}^{2}\right)$ & $5.7 \pm 0.41^{\mathrm{a}}$ & $9.7 \pm 0.71^{b}$ & $23.3 \pm 3.34^{c}$ & $56.3 \pm 5.33^{d}$ \\
\hline Volume $\left(\mu \mathrm{m}^{3}\right)$ & $8.9 \pm 1.28^{\mathrm{a}}$ & $20.9 \pm 2.55$ & $00.8 \pm / .34$ & $278.0 \pm 17.85^{\mathrm{d}}$ \\
\hline
\end{tabular}

* The values are means \pm SD $(n=30)$ of triplicate groups. Differences among the experimental groups are significant at this level. Values in the same column not sharing a superscript letter are significantly different $(p<0.05)$. Surface area $=1 / 4 \times a b \pi$ and volume $=4 / 3 \times \pi(a / 2)$ $\times(b / 2)^{2}$, where $a=$ the major axis of the cell or nucleus, $b=$ the minor axis of the cell or nucleus (Park \& Kim, 2000).

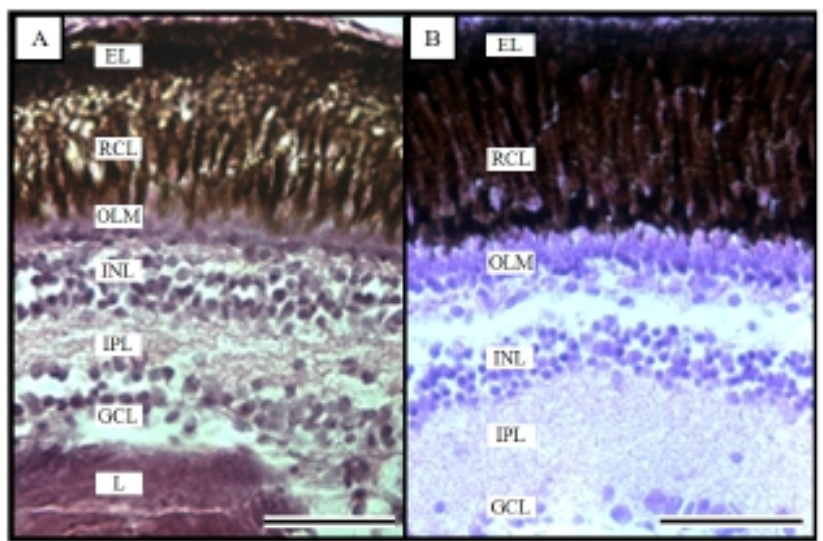

Fig. 1. Histological sections of the eye of the Ussurian bullhead, Leiocassis ussuriensis. A: Eye at just-hatched; B: eye at 50 days post-hatching. EL: epithelial layer; GCL: ganglion cell layer; INL: inner nuclear layer; IPL: inner plexiform layer; L: lens; OLM: outer limiting membrane; RCL: rod and cone layer. Scale bars are $5 \mu \mathrm{m}$.

Fig. 1 shows the histological changes in the eye of the Ussurian bullhead from just-hatched to $50 \mathrm{DPH}$. Fig. 1A shows the just-hatched eye, which has a much looser layer structure than the eye at $50 \mathrm{DPH}$, shown in Fig. 1B. In particular, the RCL and OLM are loose immediately after hatching, but become densely concentrated by 50 DPH. Fig. 2 shows the histological changes in the eye of the Korean bullhead from just-hatched to $50 \mathrm{DPH}$. In Fig. 2A, the just-hatched eye has a much looser layer structure than that of the eye at $50 \mathrm{DPH}$, shown in Fig. 2B. In particular, the RCL and OLM are loose just after

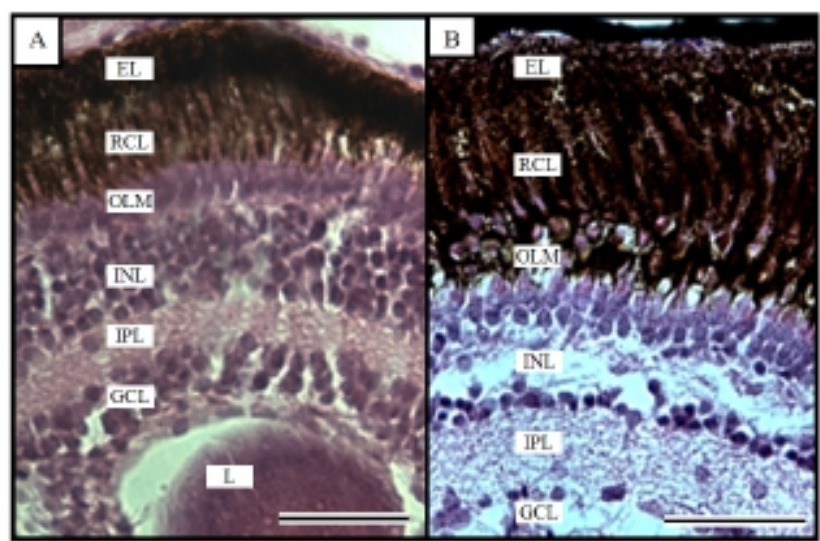

Fig. 2. Histological sections of the eye of the Korean bullhead, Pseudobagrus fulvidraco. A: Eye at just-hatched; B: eye at 50 days post-hatching. EL: epithelial layer; GCL: ganglion cell layer; INL: inner nuclear layer; IPL: inner plexiform layer; L: lens; OLM: outer limiting membrane; RCL: rod and cone layer. Scale bars are $5 \mu \mathrm{m}$.

hatching, but are densely concentrated at $50 \mathrm{DPH}$. Both species showed gradually increasing retinal density with development.

Fig. 3 shows the histological changes in the kidney and midgut epithelium of the Ussurian bullhead from just-hatched to $50 \mathrm{DPH}$. The kidney consists of many proximal tubules, which appear as hollow ovals or circles. Fig. 3B shows the kidney at $50 \mathrm{DPH}$, which has more and larger proximal tubules than the just-hatched kidney in Fig. 1A. Of the three tissues examined in this study, the greatest differences were seen in the midgut epithelium during the 50 days 


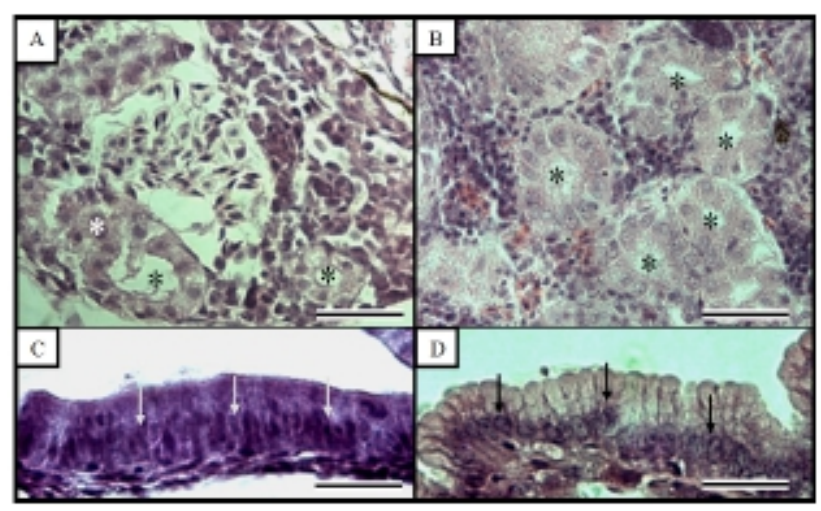

Fig. 3. Histological sections of the kidney and midgut epithelium of the Ussurian bullhead, Leiocassis ussuriensis. A: Kidney at just-hatched; B: kidney at 50 days post-hatching (DPH); C: midgut epithelium at just-hatched; D: midgut epithelium at $50 \mathrm{DPH}$. Asterisks indicate proximal tubules. Arrows indicate midgut epithelium nuclei. Scale bars are $5 \mu \mathrm{m}$.

of the experiment. The midgut epithelium at just-hatched (Fig. 3C) is tightly stretched but that at $50 \mathrm{DPH}$ (Fig. 3D) is wrinkled and folded, and the density of the tissues has increased (Fig. 3D). Fig. 4 shows the histological changes in the kidney and midgut epithelium of the Korean bullhead from just-hatched to $50 \mathrm{DPH}$. The kidney consists of many proximal tubules, which appear as hollow ovals or circles. Fig. 4B shows the kidney at $50 \mathrm{DPH}$, which has more and larger proximal tubules than the just-hatched

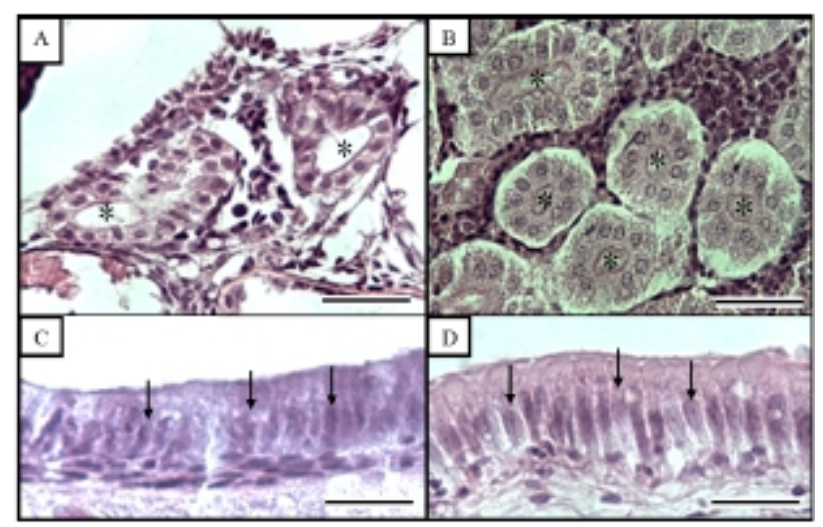

Fig. 4. Histological sections of the kidney and midgut epithelium of the Korean bullhead, Pseudobagrus fulvidraco. A: Kidney at just-hatched; B: kidney at 50 days post-hatching (DPH); C: midgut epithelium at just-hatched; D: midgut epithelium at $50 \mathrm{DPH}$. Asterisks indicate proximal tubules. Arrows indicate midgut epithelium nuclei. Scale bars are $5 \mu \mathrm{m}$. kidney (Fig. 2A). Of the three tissues examined in this study, the greatest changes were seen in the midgut epithelium during the 50 days of the experiment. The midgut epithelium at just-hatched (Fig. 4C) is tightly stretched, but that at $50 \mathrm{DPH}$ (Fig. 4D) is wrinkled and folded, and the density of the tissue has increased (Fig. 4D). A comparison of the histological changes in the kidneys and midgut epithelia of the two species showed increases in tissue density and histological changes with time.

\section{DISCUSSION}

In the teleostei, the eye usually continues to grow into adulthood, but the optical characteristics of the eye components stabilize in the early days of development, and the eyes of the Ussurian bullhead, Leiocassis ussuriensis, and the Korean bullhead, Pseudobagrus fulvidraco, were completely formed just after hatching. Their retinas are composed of six layers, being EL, GCL, INL, IPL, OLM, and RCL (Figs. 1 and 2), and each layer showed characteristics similar to those of other cyprinid fish (Takashi, 1982). In this study, trends of the retina layer changed were similar in the two species, which is consistent with the observations of Park \& Kim (2000). Similar research has been conducted in the dark-banded rockfish, Sebastes intermis, in which the RCL did not change significantly during development, whereas there was a significant change in the OLM (Park et al., 2012), and similar result in the cyprinid loach, Misgurnus anguillicaudatus (Han et al., 2013). This result is contrary to our observations in the Ussurian bullhead and Korean bullhead. Based on the results of this study and the intrinsic functions of the retinal components, we infer that the rates of change in the retinal components of fish are related to their physiology and ecology in the early days of their development.

The early development of internal organs does not differ in most Teleostei (Blaxter, 1988). Generally, there are two types of renal development, with the kidney forming either before or after hatching. Proximal tubules 
exist in kidney and using to indicator for histological comparison, proximal tubule cells measured such as major axes and minor axes (Han et al., 2013). Most aspects of the kidney tissues were similar in the two species examined here, although the Ussurian bullhead had more and larger proximal tubules than the Korean bullhead (Figs. 3 and 4). In this study, the kidneys of the Ussurian and Korean bullheads were already formed when the fish hatched and were fully developed by $50 \mathrm{DPH}$. This tendency has also been observed in the dentex, Dentex dentex and cyprinid loach, which has a fully formed kidney at hatching, which continues to grow thereafter (Santamaria et al., 2004; Han et al., 2013).

Nuclei height of midgut intestine epithelium was using the indicator for histological research, hence used to nuclei height of midgut intestine epithelium for comparative two species in this experiment (Theilacker, 1978; Park, 2006, Han et al., 2013). Most aspects nuclear height of the midgut epithelial were also similar in the two species, although the nuclear height was flatter in the Korean bullhead (Tables 3 and 4; Figs. 3 and 4). It has been reported that the absorptive function of the alimentary canal in fish begins to function either before or after the absorption of the yolk sac. In the juvenile Coregonus fera, the yolk sac is completely absorbed by $11 \mathrm{DPH}$, and during this period the absorptive activity of the midgut epithelium begins to function (Loewe \& Eckmann, 1988). In the juvenile summer flounder, Paralichthys dentatus, the yolk sac is completely absorbed by $3 \mathrm{DPH}$ and the absorptive activity of the midgut epithelium begins to function at 4 DPH (Bisbal \& Bengtson, 1995). However, in the juvenile pike eel, Muraenesox cinereus, the absorptive function of the midgut epithelium begins at $3 \mathrm{DPH}$, before the complete absorption of the yolk sac. Although the mucosal fold of the midgut has not formed at this time, the microvillous structures are detectable in the midgut with optical microscopy, and the active absorption of horseradish peroxidase is detectable in these cells, so liquefactive nutriments can be absorbed at this time (Otake et al., 1995). As soon as the Ussurian bullhead and Korean bullhead hatched, their midguts were already present and grew gradually to $50 \mathrm{DPH}$. This tendency has also been observed in the cyprinid loach (Han et al., 2013). Because the yolk sac was only completely absorbed after $14 \mathrm{DPH}$ in both species, the absorptive function of the midgut must begin before the yolk sac is completely absorbed in these species, as in the pike eel or cyprinid loach.

As mentioned above, there has been little research into the early growth of the Ussurian bullhead and Korean bullhead, which share the same family and similar habitats. In this study, we examined the histological development of both species from $1 \mathrm{DPH}$ to $50 \mathrm{DPH}$. Our results may provide useful information for the successful rearing of the Ussurian bullhead and Korean bullhead.

\section{ACKNOWLEDGMENTS}

This research was funded by project no. 2010-0021293 of the National Research Foundation of Korea, Republic of Korea. The comments of anonymous reviews greatly improved the quality of the manuscript. We declare that all experiments in this study comply with the current laws of Republic of Korea (Ordinance of Agriculture, Food and Fisheries, No. 1, Regarding Experimental Animals, no. 9932) and the Research Ethics Guidelines of Korea Maritime and Ocean University, Republic of Korea.

\section{REFERENCES}

Bisbal GA, Bengtson DA (1995) Development of the digestive tract in larval summer flounder. J Fish Biol 47:277-291. Blaxter JHS (1988) Patterns and variety in development. In: Hoar WS, Randall DJ (eds), Fish Physiology. Academic Press, New York, pp. 1-58.

Han HK, Lim SG, Kang JH, Choi JW, Gil HW, Cho SH, Lim SY, Park I-S (2013) Morphometric and histological changes in cyprinid loach, Misgurnus anguillicaudatus, in the early growth period. Dev Reprod 17:187-198. Kim IS, Park JH (2002) Freshwater Fishes of Korea. Kyo-Hak Publishing Co., Ltd, Seoul, pp. 252-259. 
Lee CY (1993) About Korean endemic bagridae fishes. Kor J Ichthyol 5:133-134.

Lim SG, Kim YS, Han HK, Kim KS, Kim DJ, Kang EJ, Son SG, Kim EO (2012) Induction of ovulation by hormone treatment in Ussurian bullhead, Leiocassis ussuriensis. Dev Reprod 16:271-277.

Loewe H, Eckmann R (1988) The ontogeny of the alimentary tract of coregonid larvae: normal development. J Fish Biol 33:841-850.

Lythgoe JN (1979) The Ecology of Vision. Clarendon Press, Oxford, pp. 1-261.

Otake T, Hirokawa J, Fujimoto H, Imaizumi K (1995) Fine structure and function of the gut epithelium of pike eel larvae. J Fish Biol 47:126-142.

Park I-S (2006) Histological changes of hepatocyte and intestinal epithelium during starvation in olive flounder Paralichthys olivaceus. J Korean Fish Soc 39:303-307.

Park I-S, Im JH, Jang CI (1996) A study on the yolk absorption and early growth in the alevin of rainbow trout, Oncorhynchus mykiss. Kor J Ichthyol 8:49-55.

Park I-S, Im SY, Hur JW, Jeong GS (2006a) Early growth and development of eye in dotted gizzard shad, Konosirus punctatus. Dev Reprod 10:93-96. (in Korean with an English abstract)

Park I-S, Kim DS (2000) Comparison of some tissues in diploid and triploid hybrid between mud loach, Misgurnus mizolepis and cyprinid loach, M. anguillicaudatus. Dev Reprod 4:19-28. (in Korean with an English abstract)

Park I-S, Lee CL (1996) Cytogenetic analysis of bagrid catfish, Pseudobagrus fulvidraco (Teleostomi: Siluriformes). Kor J Ichthyol 8:10-15.
Park I-S, Park HJ, Gil HW, Goo IB (2012) Early growth and characteristic of histological eye development in post parturition dark banded rockfish, Sebastes inermis. Dev Reprod 16:101-106. (in Korean with an English abstract)

Park I-S, Seol DW, Cho SH, Song YC, Choi HJ, Noh CH, Myoung JG, Kim JM (2006b) Morphogenesis of the eye of brown croaker (Miichthys miiuy). Ocean Polar Res 28:287-290.

Rodriguez A, Gisbert E (2001) Morphogenesis of the eye of Siberian sturgeon. J Fish Biol 59:1427-1429.

Santamaria CA, Marin de Mateo M, Traveset R, Sala R, Grau A, Pastor E, Sarasquete C, Crespo S (2004) Larval organogenesis in common dentex, Dentex dentex L. (Sparidae): histological and histochemical aspects. Aquaculture 237:207-228.

Takashi H (1982) An Atlas of Fish Histology. Kodansha Ltd, Tokyo, p. 147.

Theilacker GH (1978) Effect of starvation in the histological and morphological characteristics of jack mackerel, Trachurus symmetricus, larvae. Fish Bull 76:403-414. Wagner HJ (1990) Retinal structure of fishes. In: Douglas R, Diamgoz M (eds), The Visual System of Fish. Chapman and Hall, London, pp. 109-157.

Walls GL (1942) The Vertebrate Eye and Its Adaptive Radiation. Facsimile edition. Hafner Publishing Co., New York, pp. 1-302.

Zhang CI, Sohn MH, Seong KB, Park I-S (1995) Yolk absorption and growth of chum salmon, Oncorhynchus keta alevin. Kor J Fish Aquat Sci 28:539-548. (in Korean with an English abstract) 